Georgia State University

ScholarWorks @ Georgia State University

Counseling and Psychological Services Faculty Department of Counseling and Psychological Publications

2016

\title{
Biracial Group Membership Scale
}

\author{
Marisa Franco \\ Georgia State University, mfranco@gsu.edu \\ Olivia L. Holmes \\ University of Illinois at Chicago
}

Follow this and additional works at: https://scholarworks.gsu.edu/cps_facpub

Part of the Counseling Psychology Commons

\section{Recommended Citation}

Franco, M. G., \& Holmes, O. L. (2017). Biracial Group Membership Scale. Journal of Black Psychology, 43(5), 435-450. https://doi.org/10.1177/0095798416657260.

This Article is brought to you for free and open access by the Department of Counseling and Psychological Services at ScholarWorks @ Georgia State University. It has been accepted for inclusion in Counseling and Psychological Services Faculty Publications by an authorized administrator of ScholarWorks @ Georgia State University. For more information, please contact scholarworks@gsu.edu. 


\section{Biracial Group Membership Scale}

$5 / 8 / 2016$ 


\begin{abstract}
With individuals of mixed African heritage increasingly identifying as Biracial, it is important to determine whether Black people continue to perceive Biracial people as members of their community. The status of Biracial individuals within the Black community has implications for the political power of the Black community and also for Biracial individuals' racial identity development and well-being. Thus, the purpose of this study was to create a psychometrically sound measure to assess the degree to which Black people accept Biracial people as members of the Black community: the Biracial Group Membership Scale (BGMS). Factor analyses were conducted with 328 Black adults. Exploratory factor analysis revealed two factors: Rejection of Biracial People and Forced Black Identity. A confirmatory factor analysis provided support for the initial factor structure. The scale related to the Attitudes Towards Multiracial Children Scale, essentialism, and items assessing interactions with Biracial individuals. Limitations, suggestions for future research, and implications are discussed.

Keywords: Biracial; Multiracial; Group Membership; Black; Measure
\end{abstract}




\section{Introduction}

In 2008, CNN debuted a documentary entitled "Black in America," which explored the status of mixed race individuals amidst the Black community (Timko, 2008). Historically, such a topic would not warrant any investigation, as mixed race individuals of African heritage were incontrovertibly and legally classified as Black. This classification system was grounded in the one-drop rule, which indicated that only a drop of Black blood makes one Black. However, in the years superseding this documentary, a Biracial identity had gained traction, leading individuals who might have historically identified as Black to seek out a new identity as Biracial (Rockquemore, Brunsma, \& Delgado, 2009). Yet, in seeking such an identity, some Biracial people have received "conditional acceptance" by Black peers and have been accused of betraying the Black community through their identity choice (Leverette, 2009; Thornton, 2009). For many Biracial individuals, the Black community is the only identifiable racial home, as the Biracial community is dispersed and disparate and composed of individuals of varied ethnicities and differing racial experiences (Shih \& Sanchez, 2005). Consequently, the loss of a Black community for Biracial individuals has negative influences on their racial identity, and mental health (Franco \& Franco, 2015; Samuels, 2009). Thus, it is important to examine whether Biracial people continue to be accepted as members of the Black community and the purpose of the current study is to create a measure that assesses this: the Biracial Group Membership Scale (BGMS).

The present study defines Biracial as individuals who identify as such and are of Black and White racial heritage. We chose the term "Biracial" instead of "Multiracial" to provide increased specificity regarding racial heritage. We choose to focus on Black/White Biracial individuals' acceptance by the Black community for a number of reasons. First, Black/White 
Biracial individuals comprise the largest population of self-identified Multiracial individuals with Black ancestry by a margin of over 1.5 million (U.S. Census, 2010). Accordingly, whether this Multiracial subgroup is considered Black will have the greatest implications for the size, and subsequent political power, of the Black community. Secondly, they may be the Multiracial group that is least likely to be accepted. Their exclusion may be explained by Black community's suspicion towards Whiteness, based in the historical legacy of racial oppression exercised by White people (Whaley, 2001; Ridley, 1984). Qualitative reports from Black/White Biracial women indicate that darker-skinned Black women have rejected their Black identity because Biracial women receive dating privileges amongst Black men because of their more Eurocentric features (Rockquemore \& Brunsma, 2001). More generally, perceived access to White privilege amongst Black/White Biracial individuals may lead to resentment and questioned allegiances from members of the Black community (Rockquemore \& Brunsma, 2001; Root, 1998; Samuels, 2010). For these reasons, we think it is important to focus on the acceptance of Black/White Biracial individuals amidst the Black community.

\section{Status of Biracial People within the Black Community}

Historically, due to the legally designated one-drop rule, Biracial people were assumed to be members of their lowest-status racial heritage. This rule was created to allow White slave owners to sexually exploit their Black female slaves and profit economically from the mixed race children birthed (Rockquemore \& Laszloffy, 2003). However, since then, the one-drop rule has been upheld within the Black community; the National Association for the Advancement of Colored People (NAACP) lobbied against a Biracial identity in order to maintain their numbers, along with the political and social power of the Black community (Rockquemore \& Laszloffy, 2003). Still, Biracial people report experiences of rejection within the Black community. 
Specifically, Biracial people are rejected because their ambiguous appearance may not align with other members of their racial group, their behaviors or cultural practices may not fit with perceived group norms, and they may have perceived allegiances with an out group ancestry (Franco, Katz, \& O’Brien, 2016; Romo, 2011; Samuels, 2009). Furthermore, a Biracial identity may be perceived as betrayal and denial of one's Blackness (Leverette, 2009; Rockquemore \& Laszloffy, 2003; Thornton, 2010).

The status of Biracial individuals as members of the Black community has implications for both Biracial individuals and the Black community as a whole. Specifically, because the Biracial community is dispersed, often the Black community is the only racial home with which Biracial individuals can identify (Franco \& Franco, 2015) and as a result many choose to identify with their minority ancestry (Townsend, Fryberg, Wilkins, \& Markus, 2012). A racial home provides Biracial people with belonging, identity development, and a place to cope with racial stressors (Binning, Unzueta, Ho, \& Molina, 2009; Miville, Constantine, Baysden, \& So-Lloyd, 2005; Sellers, Caldwell, Shmeelk-Cone, \& Zimmerman, 2003; Vivero \& Jenkins, 1999); thus, rejection by the Black community could hamper Biracial people's racial identity development and put them at psychological risk (Franco \& Franco, 2015). Secondly, because rejection by Black people pushes Biracial people away from establishing a Black identity (Rockquemore \& Brunsma, 2002), Black people's rejection of Biracial individuals may lead to fewer Biracial individuals identifying with their Black identity, and subsequently, has implications for the size and political clout of the Black community. Allocation of resources to the Black community is partially contingent on the number of individuals identifying as Black. For these reasons, it is important to create an instrument to assess Biracial people's status within the Black community. 


\section{Validity Measures for Biracial Group Membership Scale (BGMS)}

In order to assess the validity of the Biracial Group Membership Scale (BGMS), the scales relation to theoretically related constructs will be assessed. Scales to assess validity were specified according to the contact hypothesis and essentialism theory.

First, grounded in the contact hypothesis, we hypothesized that increased inter-group contact would relate to increased acceptance of Biracial people as part of the Black community. The contact hypothesis indicates that increased interaction across groups leads to more positive evaluations, alongside increasing acceptance and tolerance of group members (Allport, 1954; see Hewstone \& Swart, 2011 and Pettigrew \& Tropp, 2008 for reviews), and decreased generalizations that promote social distance between groups, thus increasing a sense of similarity. Furthermore, according to Allport (1954) contact could promote empathy and perspective taking, which may lend its self to Black people accepting Biracial people's choice in their racial identity. We devised a number of items related to inter-group contact (see contact hypothesis items in measures) and hypothesized that they would relate to decreased rejection of Biracial individuals as members of the Black community.

Secondly, because the contact hypothesis purports that positive evaluations of out group members occur in tandem with tolerance, acceptance and perceptions of inter-group similarities (Pettigrew \& Tropp, 2008), we hypothesized that positive perceptions of Multiracial individuals would contribute to decreased rejection of them. Specifically, we hypothesized relations between positive perceptions of Multiracial children—assessed utilizing the Attitudes Toward Multiracial Children Scale (AMCS; Jackman, Wagner, \& Johnson, 2001)—and decreased rejection of Biracial individuals. Additionally, the utilization of the AMCS was deemed appropriate because 
it is the only psychometrically established measure assessing evaluative perceptions of Multiracial individuals.

Psychological essentialism beliefs may also influence Black people's perceptions of Biracial people. Racial essentialism is the belief that group members share an immutable essence: inherent, unchangeable, homogenized qualities (Gelman, 2003; Ho, Roberts, \& Gelman, 2015). Racial essentialism beliefs predict the use of hypodescent, the categorization of a Biracial person with their minority ancestry (Ho et al., 2015; Chao, Hong, \& Chiu, 2013; Eberhardt, Dasgupta, \& Banaszynski, 2003). Thus, racial essentialism beliefs may foster rejection of individuals identifying as Biracial, as this identity violates the distinct boundaries assumed between groups. Furthermore, Biracial peoples' ancestral Whiteness may be perceived as a threat to essentialized notions of Blackness (Young, Sanchez, \& Wilton, 2013). Biracial peoples' genetic proximity to Whiteness may be worrisome to Blacks who want the group to remain exclusive and distinct. Therefore, Black people high in racial essentialism may choose to reject Biracial individuals to maintain perceived group homogeneity and cohesion.

\section{Hypotheses}

The BGMS was hypothesized to have adequate reliability and a stable factor structure. Because higher scores on the BGMS indicate increased rejection of Biracial people as members of the Black community, it was hypothesized that the BGMS would be negatively correlated with the AMCS scale, and other items created to assess level of interaction with Biracial individuals. The BGMS was also hypothesized to positively correlate with belief in racial essentialism (Williams \& Eberhardt, 2008). A four-factor structure was hypothesized (see item development for more details).

\section{Method}




\section{Measures}

Biracial Group Membership Scale. Based on a review of the literature and videos of Black/White Biracial people discussing experiences in the Black community, we identified a number of factors relevant to determining Black people's perceptions of Biracial people as outgroup members (e.g. culture, community, identification, perceptions of White identity, hypodescent) and we developed an initial pool of 19 items. After revising the items, we sent the scale to six Black psychologists and doctoral students to provide open-ended feedback. As a result, we added six additional items to the scale, which produced a 25 item measure with the following four subscales: Closeness to Biracial people (e.g., "I do not feel connected with Biracial people like I do with Black people”), Perceptions of Biracial people's place within the Black Community (e.g., "Biracial people are not members of the Black community"), Acceptance of Biracial identity (e.g., "Biracial people should identify as Black") and Black identity (e.g., "Biracial people have an obligation to the Black community to identify as Black"). Items were measured on a 7-point likert scale (Strongly Disagree to Strongly Agree). Instructions indicated that "Biracial" refers to individuals who have a Black parent and a White parent and identify as Biracial. Higher scores indicated perceptions of Black/White Biracial people as outgroup members. One item was added for an attention check: "Please click agree."

Contact hypothesis items. Three items assessing inter-group contact with Biracial people were included to assess validity: I know Biracial people, I have Biracial people in my family, and I interact with Biracial people often. Items were measured on a 7-point likert scale (Strongly Disagree to Strongly Agree).

Attitudes Towards Multiracial Children. An abridged 8-item version of AMCS scale (Jackman et al., 2001; $\alpha=.76$ ) was administered. AMCS measures perceptions of the cost and 
benefits of possessing a Multiracial identity. Items were rated on a five-point scale ranging from 1 (strongly disagree) to 5 (strongly agree), in which higher scores indicated positive attitudes toward Multiracial people. A representative item is, "Biracial people benefit from having parents of different racial backgrounds."

Race Conceptions Scale. The 22-item Race Conception Scale (Williams \& Eberhardt, 2008; $\alpha=.82$ ) was used to assess racial essentialism: the extent to which an individual conceives race as biologically based. Items were rated on a seven-point scale ranging from 1 (strongly disagree) to 7 (strongly agree), in which higher scores indicated biological conception of race and lower scores indicated social conception of race. A representative item is, "A person's race is fixed at birth."

\section{Procedure}

Black participants were recruited via online communities such as Facebook groups, as well as through a mid-Atlantic University registrar $(N=328)$ to complete an online study. Participants accessed measures via Qualtrics, an online survey platform, where they were given informed consent followed by demographic items (age, gender, sex, income, etc.), contact hypothesis items, the BGMS, AMCS, and the Race Conceptions Scale. Items were shown to participants in random order. Additional scales were administered that were used for a separate study measuring mediating factors that might determine the degree to which Black people accept Biracial people.

\section{Results}

Participant data were randomly split across two samples, the first used for the exploratory factor analysis and the second for the confirmatory.

\section{Sample One}


Participants. Participants included 164 adults (118 women, 44 men, 1 other), ranging in age from 18 to 73 years old, with a mean age of $25.77(S D=11.66)$. Approximately $46.4 \%$ of participants reported their family income as greater than $\$ 80,000$ per year, whereas $31.1 \%$ earned between $\$ 40$ and 79,000 and 22.6\% averaged a family income below $\$ 40,000$. Most (75.6\%) reported being "completely heterosexual", while a few (.6\%) reported being "completely gay" and the remainder $(23.8 \%)$ rated themselves as somewhere between the poles. Approximately $17.7 \%$ of the sample finished high school, whereas $35.4 \%$ finished some college, $6.7 \%$ finished an associate's degree, $17.7 \%$ finished a bachelor's degree, and 20.7\% reported a graduate degree.

Factor analysis for sample 1. First, an examination of communalities and of the factorability of the data was conducted to determine if the data was sufficient for conducting factor analyses. Communality values for items ranged from .52-66, indicating that there was a moderate amount of shared variance across items. For communalities in this range, 100-200 participants are adequate (Kahn, 2006; MacCallum, Browne, \& Sugawara, 1999). Thus, even though the sample size was relatively small, it can be considered sufficient in light of the moderately high communality scores. Factorability of the data set was deemed appropriate using the Kaiser-Meyer-Olkin Measure of Sampling Adequacy (KMO) and Bartlett's test of sphericity, $\mathrm{KMO}=.86$, Bartlett's $=\chi^{2}(300, N=164)=1625.81, p<.001$

Initially, a principal factor analysis with direct oblimin rotation was computed on all 25 items using the hypothesized four-factor solution. However, factor loadings revealed several issues: one-item factors, issues of cross loadings, and lack of conceptual clarity. Subsequently another analysis was run with no suggested factor solution. The scree plot was examined which suggested a two, three, four, or five factor solution, accounting for $28.44 \%, 41.25 \%, 47.19 \%$ and $52.29 \%$ of the variance, respectively. Three additional principal factor analyses were computed, 
with two, three, and five factors extracted. Each factor solution was considered to identify the solution with the highest loading items with fewest cross-loadings, robust variance explained, conceptual clarity, and each factor containing at least 4 items (to increase the likelihood of factor reliability). The two-factor solution best adhered to these criteria. To retain the most robust items on the measure, only the 5 highest loading items on each factor were retained. A final exploratory factor analysis was conducted with these 10 items. Each of these items loaded above .6 on a single factor, and did not load above .2 on another. These items collectively accounted for $59.58 \%$ of the variance. Factor loadings can be found in Table 1. [Insert Table 1 here]

Factor one: Rejection of Biracial People. The first factor is entitled "Rejection of Biracial People" and assessed rejection of Biracial people as members of the Black community. An example item is "Biracial people are not members of the Black community."

Factor two: Forced Black Identity. The second factor is entitled "Forced Black Identity" and assessed the degree to which participants thought that Biracial people should identify as Black. An example item is "Biracial people should identify as Black."

\section{Sample Two}

Participants. Participants included 164 adults (110 women, 52 men, 2 other) ranging in age from 18 to 71 years old, with a mean age of $23.10(S D=8.34)$. Approximately $45.7 \%$ of participants reported their family income as greater than $\$ 80,000$ per year, whereas $31.1 \%$ earned between $\$ 40$ and 79,000 and 23.2\% averaged a family income below $\$ 40,000$. Most (76.2\%) reported being "completely heterosexual," whereas a few $(3.0 \%)$ reported being "completely gay" and the remainder (20.8\%) rated themselves as somewhere between the poles.

Approximately $20.1 \%$ of the sample finished high school, whereas $45.1 \%$ finished some college, 
4.3\% finished an associate's degree, $17.7 \%$ finished a bachelor's degree, and $11.0 \%$ reported a graduate degree.

Factor analysis. To test the 2-factor model, a confirmatory factor analysis using maximum likelihood estimation was conducted using Mplus. After running the confirmatory factor analysis with the two factor measure, the fit indices were adequate: $\chi 2(34, \mathrm{~N}=164)=$ 99.19, $\mathrm{p}<.001, \mathrm{RMSEA}=.11,95 \% \mathrm{CI}[.08,14], \mathrm{CFI}=.86$, and TLI $=.82$. Although some indices met more liberal fit thresholds, the two-factor solution as also supported by its conceptual and theoretical clarity. All items had factors loadings above .5 for each of their respective factors and were significant. Model modification indices for all items were under 100, indicating nonoverlapping loadings.

\section{Reliability and Validity Analyses With Entire Sample}

The two factors were allowed to correlate and exhibited moderate correlations, $(328)=$ $.30, \mathrm{p}<.001$. In line with hypotheses, the Rejection of Biracial People subscale $(\alpha=.79 ; M=$ 2.20; $S D=1.08)$ negatively correlated with "I know Biracial people," $r(328)=-.17, \mathrm{p}<.01$, "I have Biracial people in my family," $r(328)=-.13, \mathrm{p}<.05$, and "I interact with Biracial people often," $r(328)=-.35, \mathrm{p}<.001$ items, and with the AMCS, $r(328)=-.29, \mathrm{p}<.001$, and it positively correlated with the Race Conceptions Scale $r(328)=.24, \mathrm{p}<.001$. In line with hypotheses, The Forced Black Identity subscale $(\alpha=.81 ; M=3.15 ; S D=1.31)$ negatively correlated with "I interact with Biracial people often," $r(328)=-.15, \mathrm{p}<.01$ item and with AMCS, $r(328)=-.22, \mathrm{p}<.001$, and it positively correlated with the Race Conceptions scale $r$ $(328)=.20, \mathrm{p}<.001$. The Forced Black Identity scale did not correlate with the "I know Biracial People" and "I have Biracial People in my family" items. No differences were found in subscale scores based on gender. 


\section{Discussion}

The question of "Who is Black in America?" can be investigated by assessing in-group perspectives of the Black community. This question is important to address in order to understand the size, scope, and heterogeneity within current definitions of Blackness, which has implications for the community's resource allocation and political power (Rockquemore \& Laszloffy, 2003). Furthermore, addressing whether Biracial people are accepted within Black spaces has implications for the racial identity development, belonging, social support, and discriminatory coping, and subsequently, the mental health, of Biracial individuals (Franco \& Franco, 2015; Shih \& Sanchez, 2005; Sanchez, 2010). The present study is thought to create a foundation for addressing this question, through the development of the BGMS.

The BGMS included two factors: Rejection of Biracial People and Forced Black Identity. These factors exhibited moderate correlations indicating that individuals likely to reject Biracial people as part of the Black community may also be likely to impose a Black identity on Biracial people. This suggests a complex relationship, whereby Biracial people may be simultaneously be rejected as and pressured to be Black. This relation may be disguising more complex inter group relationships, whereby Biracial people may be accepted within the Black community to the extent to which they identify as Black (Thornton, 2009). However, it is important to note that this relationship is moderate, suggesting that these two factors are distinct, indicating that a Black identity may not always be a requisite to racial group acceptance for Biracial individuals.

Overall, the scale has evidence of being psychometrically sound. The BGMS factor structure was upheld across a confirmatory factor analyses and the scale items attest to the face validity and conceptual clarity of the scale. The scale's validity was further supported by its adequate reliability rates, and its relation to scales and items measuring theoretically similar 
constructs: items assessing interaction with Biracial individuals, the AMCS (Jackman et al., 2001), and racial essentialism (Williams \& Eberhardt, 2008). In corroboration with the contact hypothesis, all items assessing level of contact with Biracial individuals related inversely to the Rejection of Biracial People subscale, which indicates that interaction with Biracial people might foster feelings of similarity, and thus, acceptance of Biracial people as members of the Black community. On the other hand, the Forced Black Identity subscale was only related to the "I interact with Biracial people often" item, and not the two other items assessing validity: "I know Biracial People," and "I have Biracial People in my family." Furthermore, correlations between the Rejection of Biracial People subscale and these latter items were significant, but low. It may be that these latter items do not necessarily indicate in-depth interaction and closeness necessary to foster Black people's affirmation of Biracial people's identity choice; these items may be limited in their ability to assess the level of continued interaction necessary to promote feelings of similarity, closeness, and empathy that arise in accordance with The Contact Hypothesis. This may suggest that in-depth rather than superficial contact between Biracial and Black people is necessary to promote Black people accepting Biracial people's racial identity. Significant and negative moderate correlations between BGMS and AMCS provide additional support for relations between positive evaluation and feelings of similarity and inclusion — as indicated by The Contact Hypothesis — and also suggest that the two instruments were measuring distinct constructs. The consistent relationships between BGMS subscales and racial essentialism suggest that perhaps one way to promote increased acceptance of Biracial people amongst the Black community would be to challenge Black people's racially essentialist beliefs.

There may be important implications for Black people's acceptance of Biracial people that influence race relations amidst these communities. According to social comparison theory, 
individuals elevate the status of their group, while denigrating that of out groups (McLeod, 2008). Thus, if Biracial people are marked as an out-group, they will be more likely to face negative treatment from Black people, and this out-group demarcation may be a contributing factor as to why Biracial individuals report racial discrimination from Black people (Buckley \& Carter, 2004; Rockquemore \& Brunsma, 2002). A number of research studies have illustrated relationships between perceptions of racial out-groups, and subsequent behaviors towards members of that racial group (Flynn, 2005; Habtegiorgis, Paradies, \& Dunn, 2014). Specifically, out-group bias may manifest as interpersonal rejection, negative impression formation, and discriminatory treatment across various domains such as school and work (Dovidio, Kawakami, \& Gaertner, 2002; Flynn, 2006; Habtegiorgis et al., 2015).

To the extent that the scale can be considered psychometrically valid, it is important to mention that Black participants exhibited low rates of Biracial Rejection and Forced Black Identity, indicating that the college student sample of Black people may be more likely to both accept Biracial people within the community, and accept their Biracial identity as well. Thus, it may be that generally, a Biracial identity is perceived as being harmonious with a Black identity—not disqualifying one's self from group membership. Overall, these findings suggest that Biracial people may find racially affirming spaces amidst the Black community.

However, because the sample was limited in terms of demographic characteristicsbeing composed of educated, higher SES, college students - a major limitation is that results may not extend to other subsamples of the Black community. For example, as discussed earlier, the NAACP lobbied against a Multiracial racial designation, and in favor of a forced Black identity (Rockquemore \& Laszloffy, 2003). The measurement should be further verified through administration amongst diverse samples of Black people, including older, less wealthy, less 
educated samples. It would be particularly elucidating to investigate properties of the measure amidst a sample of Southern Black people, where the one-drop rule is more strictly enforced (Khanna, 2010). Also, further replications of the scale with diverse samples should also include additional measures of reliability, such as test-retest reliability, and discriminant validity.

Furthermore, the scale is limited in that it only assessed Black people's perspectives of Black/White Biracial people so future research might address Black people's perspectives of Biracial people of Black and non-White ancestry. Another limitation is that some fit indexes within the confirmatory analysis met liberal threshold criteria, perhaps because of the relatively small sample size (De Winter, Dodou, \& Wieringa, 2009). Additional research might further verify the factor structure of the scale using larger sample sizes. Last, validity correlations between the scale and validity measures were mostly significant, but sometimes low, which may be explained by the restricted range of the subscales or by psychometric limitations of the oneitem measures used to corroborate the contact hypothesis. Future studies might employ additional measures of validity to further support the psychometric properties of the scale.

Future research might determine predictors of perceptions of Biracial group membership so that Biracial people might be able to seek out specific affirming spaces within the Black community, as Biracial people often experience racial isolation and affirming relationships have been found to prevent against discriminatory experiences (Franco et al., 2016), and affirmation by Black people has been shown to be particularly important to Biracial people's racial identity (Franco \& Franco, 2015). In a qualitative study conducted by Franco et al. (2016), some factors found to contribute to Black/White Biracial people's rejection included their White heritage, and their non-racially prototypical phenotype and failure to perform racially stereotypical behaviors. It may be that these factors may influence the degree to which Biracial people are accepted 
within the Black community. Future research seeking to examine Biracial people's level of acceptance with the Black community might include these factors when modeling the degree to which Biracial people are accepted. There are also factors internal to Black people that might predict whether they would accept Biracial people-essentialism being one delineated in the current study. Other factors might include Black people's racial identity, conservatism, personal need for structure, phenotype, preferences for cultural homogeneity, or dialectical views on identity (Krosch, Berntsen, Amodio, Jost \& Van Bavel, 2013; Sellers, Rowley, Chavous, Shelton, \& Smith, 1997; Skinner \& Nicolas, 2015; Shih, Sanchez, \& Garcia, 2010). Furthermore, experimental studies might manipulate these factors and determine whether this intervention causes changes in Black people's acceptance of Biracial people. Because previous research has found that rejection by Black people decreases Biracial people's likelihood of choosing a Black identity (Rockquemore \& Brunsma, 2004), it may be important to investigate the interactional relationship between Black people's perceptions of Biracial people and Biracial people's identity over time. Last, research should be conducted on whether rejection of Biracial people from the Black in-group can be explained by perceptions of genetic Whiteness. Are light skinned Black people treated differently from Biracial people because Whiteness is more salient in the case of Biracial people?

With changing definitions of what it means to be Black, the status of Biracial people amongst the larger Black community has often been called into question. This is an important area to continue to investigate in order to chart the changing trajectory of the Black community, and also to help Biracial people develop a sense of identity inclusion and community; it is our hope that the BGMS may be used to catalyze a platform of research to address these topics. 


\section{References}

Allport, G. (1954). The nature of prejudice. Cambridge, MA: Addison Wesley.

Franco, M. G., \& Franco, S. A. (2015). Impact of identity invalidation for Black Multiracial people: The importance of race of perpetrator. Journal of Black Psychology. Advance online publication. doi: 10.1177/0095798415604796

Franco, M. G., Katz, R., \& O’Brien, K. (2016). Forbidden identities: A qualitative examination of racial identity invalidation for Black/White Biracial Individuals. International Journal of Intercultural Relations, 50, 96-109. doi: 10.1016/j.ijintrel.2015.12.004

Buckley, T. R., \& Carter, R. T. (2004). Biracial (Black/White) women: A qualitative study of racial attitudes and beliefs and implications for therapy. Women \& Therapy, 27, 45-64. doi:10.1300/J015v27n01_04

Chao, M. M., Hong, Y., \& Chiu, C. (2013). Essentializing race: Its implications on racial categorization. Journal of Personality and Social Psychology, 104, 619-634.

De Winter, J. C. F., Dodou, D., \& Wieringa, P. A. (2009). Exploratory factor analysis with small sample sizes. Multivariate Behavioral Research, 44, 147-181. doi: $10.1080 / 00273170902794206$

Dovidio, J. F., Kawakami, K., \& Gaertner, S. L. (2002). Implicit and explicit prejudice and interracial interaction. Journal of Personality and Social Psychology, 82, 62-68.

Eberhardt, J. L., Dasgupta, N., \& Banaszynski, T. L. (2003). Believing is seeing: the effects of racial labels and implicit beliefs on face perception. Personality \& Social Psychology Bulletin, 29, 360-70. http://doi.org/10.1177/0146167202250215

Flynn, F. J. (2005). Having an Open Mind: The Impact of Openness to Experience on Interracial Attitudes and Impression Formation. Journal Of Personality And Social 
Psychology, 88(5), 816-826. doi:10.1037/0022-3514.88.5.816

Gelman, S. A. (2003). The essential child: Origins of essentialism in everyday thought. New York, NY: Oxford University Press.

Hewstone, M., \& Swart, H. (2011). Fifty-odd years of inter-group contact: From hypothesis to integrated theory. British Journal Of Social Psychology, 50, 374-386. doi:10.1111/j.2044-8309.2011.02047.x

Jackman, C. F., Wagner, W. G., \& Johnson, J. T. (2001). The Attitudes Toward Multiracial Children Scale. Journal of Black Psychology, 27(1), 86-99.

doi:10.1177/0095798401027001005 doi:10.1177/0095798407302540

Kahn, J. K (2006). Factor analysis in counseling psychology research, training and practice: Principles, advances, and applications. The Counseling Psychologist, 34, 684-718. DOI: $10.1177 / 0011000006286347$

Khanna, N. (2010). "If you're half Black, you're just Black": Reflected appraisals and the persistence of the one-drop rule. The Sociological Quarterly, 51, 96-121. doi:10.1111/j.1533-8525.2009.01162.x

Krosch, A. R., Berntsen, L., Amodio, D. M., Jost, J. T., \& Van Bavel, J. J. (2013). On the ideology of hypodescent: Political conservatism predicts categorization of racially ambiguous faces as Black. Journal Of Experimental Social Psychology, 49(6), 11961203. doi:10.1016/j.jesp.2013.05.009

Habtegiorgis, A. E., Paradies, Y. C., \& Dunn, K. M. (2014). Are racist attitudes related to experiences of racial discrimination? Within sample testing utilising nationally representative survey data. Social Science Research, 47178-191. doi:10.1016/j.ssresearch.2014.05.002 
Ho, A. K., Roberts, S. O., \& Gelman, S. A. (2015). Essentialism and Racial Bias Jointly Contribute to the Categorization of Multiracial Individuals. Psychological Science, 1-7. http://doi.org/10.1177/0956797615596436

Leverette, T. (2009). Speaking Up: Mixed Race Identity in Black Communities. Journal Of Black Studies, 39, 434-445. doi:10.1177/0021934706297875

MacCallum, R. C., Browne, M. W., \& Sugawara, H. M. (1996). Power analysis and determination of sample size for covariance structure modeling. Psychological Methods, 1, 130-149.

Mcleod, S. (2008) Social Identity Theory. Retrieved September $8^{\text {th }}, 2014$ from http://www.simplypsychology.org/social-identity-theory.html

Miville, M. L., Constantine, M. G., Baysden, M. F., \& So-Lloyd, G. (2005). Chameleon changes: An exploration of racial identity themes of Multiracial people. Journal of Counseling Psychology, 52, 507-516. doi: 10.1037/0022-0167.52.4.507

Timko, D. (Producer), \& Timko, D. (Director). (2008). Black in America [Motion Picture], USA: CNN

Pettigrew, T., \& Tropp, L. (2008). How does intergroup contact reduce prejudice? Meta-analytic tests of three mediators. European Journal of Social Psychology, 38, 922-934. doi:10.1002/ejsp.504

Ridley, C. R. (1984). Clinical treatment of the nondisclosing Black client: A therapeutic paradox. American Psychologist, 39, 1234-1244.

Rockquemore, K. A., \& Brunsma, D. L. (2001). Beyond Black: Biracial identity in America. Thousand Oaks, CA: Sage. 
Rockquemore, K. A., \& Brunsma, D. L. (2002). Theories, typologies, and processes of racial identity among Black/White Biracials. The Sociological Quarterly, 43, 335-356.

Rockquemore, K. A., \& Brunsma, D. L. (2004) Negotiating Racial Identity: Biracial Women and interactional validation. Women and Therapy, 27, 1-2. doi: 10.1300/J015v27n01_06

Rockquemore, K. A., Brusma, D. L., \& Delgado, D. J. (2009). Racing to theory or re-theorizing race? Understanding the struggle to build a multiracial identity theory. Journal of Social Issues, 65, 13 - 34. doi: 10.1111/j.1540-4560.2008.01585.x

Rockquemore, K. A., \& Laszloffy, T. A. (2003). Multiple realities: A relational narrative approach in therapy with Black-White mixed-race clients. Family Relations: An Interdisciplinary Journal of Applied Family Studies, 52, 119-128.doi: 10.1111/j.17413729.2003.00119.x

Romo, R. (2011). Between Black and Brown: Blaxican (Black-Mexican) Multiracial identity in California. Journal of Black Studies, 42, 402-426. doi:10.1177/0021934710376172

Root, M. P. P. (1998). Experiences and processes affecting racial identity development: Preliminary results from the Biracial Sibling Project. Cultural Diversity and Mental Health, 4, $237-247$.

Sanchez, D. T., Shih, M., \& Garcia, J. A. (2009). Juggling multiple racial identities: Malleable racial identification and well-being. Cultural Diversity \& Ethnic Minority Psychology, 15, 243-254. doi: 10.1037/a0014373

Samuels, G. M. (2009). 'Being raised by White people': Navigating racial difference among adopted multiracial adults. Journal Of Marriage And Family, 71, 80-94. doi:10.1111/j.1741-3737.2008.00581.x 
Samuels, G. M. (2010). Building kinship and community: Relational processes of bicultural identity among adult multiracial adoptees. Family Process, 49, 26-42. doi:10.1111/j.1545-5300.2010.01306.x

Sanchez, D. T. (2010). How do forced-choice dilemmas affect Multiracial people? The role of identity autonomy and public regard in depressive symptoms. Journal of Applied Social Psychology, 40, 1657-1677. doi: 10.1111/j.1559-1816.2010.00634.x

Sellers, R. M., Caldwell, C. H., Schmeelk-Cone, K., \& Zimmerman, M. A. (2003). The role of racial identity and racial discrimination in the mental health of African American young adults. Journal of Health and Social Behavior, 44, 302-317. doi:

$10.1177 / 0095798410390689$

Sellers, R. M., Rowley, S. A. J., Chavous, T. M., Shelton, J. N., \& Smith, M. A. (1997).

Multidimensional inventory of Black identity: Preliminary investigation of reliability and construct validity. Journal of Personality and Social Psychology, 73, 805-815. doi:10.1037/0022-3514.73.4.805

Shih, M., \& Sanchez, D. T. (2005). Perspectives and research on the positive and negative implications of having multiple racial identities. Psychological Bulletin, 131, 569-591. doi:10.1037/0033-2909.131.4.569

Skinner, A. L., \& Nicolas, G. (2015). Looking Black or looking back? Using phenotype and ancestry to make racial categorizations. Journal of Experimental Social Psychology, 57, 5563. http://doi.org/10.1016/j.jesp.2014.11.011

Thornton, M.C. (2009). Policing the Borderlands: White- and Black-American Newspaper Perceptions of Multiracial Heritage and the Idea of Race, 1996-2006. Journal of Social Issues, 65, 105-123. Doi: 10.1111/j.1540-4560.2008.01590.x 
Townsend, S. S. M., Fryberg, S. a., Wilkins, C. L., \& Markus, H. R. (2012). Being mixed: Who claims a biracial identity? Cultural Diversity and Ethnic Minority Psychology, 18(1), 9196. http://doi.org/10.1037/a0026845

U. S. Census Bureau. (2010). Overview of race and Hispanic origin: 2010. Retrieved November 23, 2011, from http://www.census.gov/prod/cen2010/briefs/c2010br02.pdf

Vivero, V. N., \& Jenkins, S. R. (1999). Existential hazards of the multicultural individual: Defining and understanding "cultural homelessness". Cultural Diversity \& Ethnic Minority Psychology, 5, 6-26.

Williams, M. J., \& Eberhardt, J. L. (2008). Biological conceptions of race and the motivation to cross racial boundaries. Journal of Personality and Social Psychology, 94, 1033-1047.

Young, D. M., Sanchez, D. T., \& Wilton, L. S. (2013). Crossroads of race: Racial ambiguity and biracial identification influence psychological essentialist thinking. Cultural Diversity and Ethnic Minority Psychology, 19, 461-467. 
Table 1

Principal Axis Factor Loadings for Biracial Group Membership Scale

\begin{tabular}{|c|c|c|c|c|c|}
\hline \multirow[b]{2}{*}{ Item Content by Factor } & \multicolumn{3}{|c|}{ EFA } & \multicolumn{2}{|c|}{ CFA } \\
\hline & Factor 1 & & Factor 2 & Factor 1 & Factor 2 \\
\hline \multicolumn{6}{|l|}{ Factor 1: Biracial Rejection } \\
\hline Biracial people do not count as real Black people & .82 & & -.05 & 60 & \\
\hline Biracial people cannot relate to the experiences of Black people & .79 & & .06 & .51 & \\
\hline Biracial people are not members of the Black community & .74 & &.-.13 & .67 & \\
\hline \multicolumn{6}{|l|}{ I feel as if It would be easier for me to build relationships with black people } \\
\hline rather than Biracial people & .72 & & .17 & .73 & \\
\hline I do not feel connected with Biracial people like I do with Black people & .71 & &. .20 & .58 & \\
\hline \multicolumn{6}{|l|}{ Factor 2: Forced Black Identity } \\
\hline Biracial people should identify as Black & -.05 & & .79 & & .63 \\
\hline \multicolumn{6}{|l|}{ If a Biracial person looks like they have Black ancestry, they should } \\
\hline identify as Black &. .05 & .. & .77 & & 67 \\
\hline A Biracial person who identifies as anything but Black is in denial & .02 & & .77 & & .70 \\
\hline \multicolumn{6}{|l|}{ A Biracial person who identifies as anything but Black is betraying the } \\
\hline Black community & .10 & & .76 & & .68 \\
\hline Biracial people have an obligation to the Black community to identify as Black & -.07 & & .75 & & .71 \\
\hline
\end{tabular}

